ISSN 2587-8123 (Print) ISSN 2658-5995 (Online)

МИНИСТЕРСТВО НАУКИ И ВЫСШЕГО ОБРАЗОВАНИЯ РОССИЙСКОЙ ФЕДЕРАЦИИ ВОЛГОГРАДСКИЙ ГОСУДАРСТВЕННЫЙ УНИВЕРСИТЕТ

НИЖНЕВОЛЖСКИЙ АРХЕОЛОГИЧЕСКИЙ ВЕСТНИК 2021 Tом 20. № 2

MINISTRY OF SCIENCE AND HIGHER EDUCATION OF THE RUSSIAN FEDERATION VOLGOGRAD STATE UNIVERSITY

THE LOWER VOLGA ARCHAEOLOGICAL BULLETIN 2021 Volume 20. No. 2

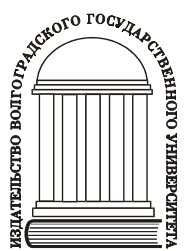




\section{СОДЕРЖАНИЕ}

Конец прекрасной эпохи (Редакциионная коллегия) .... 5

\section{СТАТЬИ}

Файзуллин И.А., Купцова Л.В., Мухаметдинов В.И. Гончарное производство срубной культуры Предуралья по материалам курганного могильника I у села Твердилово

Балабанова М.А., Клепиков В.М., Перерва Е.В. Погребальный обряд и морфология погребенного из кургана могильника Тау (Западный Казахстан) .... 24

Монахов С.Ю. Типология и хронология аканфских амфор [На англ. яз.] 43

Абрамова А.Н. Население Прикубанья раннего железного века по данным краниофенетики (предварительные данные) .66

Малашев В.Ю., Маслов В.Е. Курганы-кладбища центральных и восточных районов Северного Кавказа III в. до н.э. - начала (первой половины) II в. н.э. (памятники типа Чегем-Манаскент)

Ковалева К.С. Производственные

бронзолитейные комплексы

городов Золотой Орды: поиск аналогий

Дрёмов И.И., Круглов Е.В. Железные конусы в погребениях Улуса Джучи:

аспекты этнокультурной принадлежности 149

Гаглойты Р.Х., Кочкаров У.Ю., Мамаев Р.Х., Нарожный В.Е., Нарожный Е.И. Наконечники копий келийского каменноящечного могильника (Горная Ингушетия)

\section{ПУБЛИКАЦИИ}

Кривочеев М.В., Моисеев В.И.

Погребения раннесарматского времени

с территории Чеченской Республики

Иванов С.С. Редкая поясная бляха

в зооморфном стиле с Внутреннего Тянь-Шаня..... 196

Николаев С.Ю. Три сарматских кинжала

с подножия горы Торатау 204

\section{НАУЧНАЯ ЖИЗНЬ}

Итоги VI Нижневолжской Международной археологической научной конференции «Волго-Уральский регион от древности до Средневековья» (Оргкомитет конферениии) 214

\section{CONTENTS}

The End of a Great Era (Editorial Staff) 5

\section{ARTICLES}

Fayzullin I.A., Kuptsova L.V., Mukhametdinov V.I. The Ceramics Production of the Cis-Ural Srubnaya Culture: A Case Study of the Kurgan Cemetery I Near Tverdilovo Village ..... 8

Balabanova M.A., Klepikov V.M., Pererva E.V. Funeral Rite and Morphology of a Buried Man from Kurgan of Tau Cemetery (Western Kazakhstan) .... 24 Monakhov S.Yu. Typology and Chronology of Akanthian Amphorae

Abramova A.N. Craniophenetic Features

of Cis-Kuban Population of the Early Iron Age (Preliminary Data)

Malashev V.Yu., Maslov V.E. Kurgan-Cemeteries of Central and Eastern Regions of North Caucasus $3^{\text {rd }}$ Century BC - Early $2^{\text {nd }}$ Century AD

(Monuments Chegem-Manaskent Type)

Kovaleva K.S. Manufacturing Complexes for the Non-Ferrous Metals Processing of the Golden Horde Cities: Search for Analogies

Dremov I.I., Kruglov E.V. Iron Cones

in the Burials of Ulus Jochi:

Aspects of Ethnocultural Identification

Gagloiti R.H., Kochkarov U.U., Mamaev R.Kh., Narozhnyi V.E., Narozhnyi E.I. Spearheads of the Keliysky Stone Box Burial Ground (Ingushetia Highlands)

\section{PUBLICATIONS}

Krivosheev M.V., Moiseev V.I.

Early Sarmatian Burials

from the Chechen Republic Territory

Ivanov S.S. A Rare Belt Plaque in Zoomorphic Style from the Inner Tien Shan.... 196

Nikolaev S.Yu. Three Sarmatian Daggers

from the Foot of Toratau Mount

\section{SCIENTIFIC LIFE}

Proceedings of the $6^{\text {th }}$ Lower Volga International Scientific Conference on Archaeology

"The Volga-Ural Region -

from Antiquity to the Middle Ages"

(Organizing Committee of the Conference) 214 
www.volsu.ru

DOI: https://doi.org/10.15688/nav.jvolsu.2021.2.8

UDC 902/904

(c)

LBC 63.4

Submitted: 21.07.2021

Accepted: 30.10 .2021

\title{
SPEARHEADS OF THE KELIYSKY STONE BOX BURIAL GROUND (INGUSHETIA HIGHLANDS) ${ }^{1}$
}

\author{
Robert H. Gagloiti \\ South-Ossetian Scientific Research Institute named after Z.N.Vaneev, Tskhinval, South Ossetia \\ Umar U. Kochkarov \\ Institute of Archaeology of the Russian Academy of Sciences, Moscow, Russian Federation \\ Rashid Kh. Mamaev \\ Chechen State University, Grozny, Russian Federation \\ Vitaliy E. Narozhnyi \\ Independent Researcher, Armavir, Russian Federation \\ Evgeniy I. Narozhnyi \\ Karachay-Cherkess State University named after U.D. Aliyev, Karachaevsk, Russian Federation
}

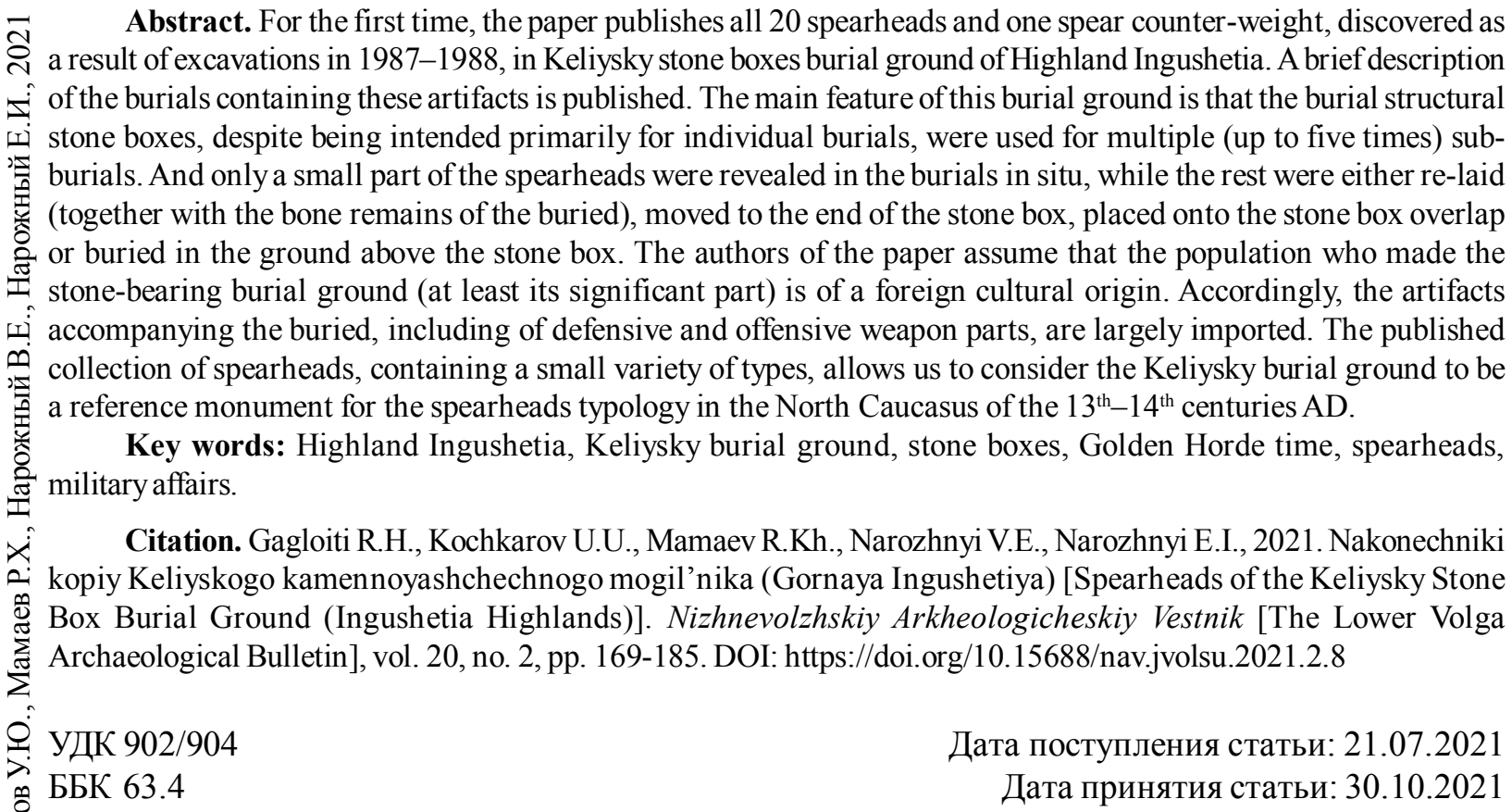

\section{НАКОНЕЧНИКИ КОПИЙ КЕЛИЙСКОГО КАМЕННОЯЩЕЧНОГО МОГИЛЬНИКА (ГОРНАЯ ИНГУШЕТИЯ) ${ }^{1}$}

\section{Роберт Хазбиевич Гаглойты}

Юго-Осетинский научно-исследовательский институт им 3.Н. Ванеева, г. Цхинвал, Республика Южная Осетия 
Spearheads of the Keliysky Stone Box Burial Ground (Ingushetia Highlands)

\section{Умар Юсуфович Кочкаров}

Институт археологии РАН, г. Москва, Российская Федерация

\section{Рашид Хамидович Мамаев}

Чеченский государственный университет, г. Грозный, Российская Федерация

\section{Виталий Евгеньевич Нарожный}

Независимый исследователь, г. Армавир, Российская Федерация

\section{Евгений Иванович Нарожный}

Карачаево-Черкесский государственный университет им. У.Д. Алиева, г. Карачаевск, Российская Федерация

Аннотация. В статье впервые публикуются все 20 наконечников копий и один вток, обнаруженные в результате раскопок 1987-1988 гг. в каменных ящиках и грунтовых погребениях Келийского могильника Высокогорной Ингушетии. Публикуется краткое описание погребений, содержащих указанные артефакты. Особенностью данного могильника является то, что погребальные сооружения - каменные ящики, предназначенные в первую очередь для индивидуальных захоронений, использовались для многократных (до 5 раз) подзахоронений. И только небольшая часть копий была зафиксирована в погребениях in situ, в то время как остальные были переотложены (вместе с костными останками погребенных) - сдвинуты в конец ящика, перемещены на его перекрытие или закопаны в грунте над ящиком. Авторы статьи предполагают инокультурное происхождение населения (по крайней мере значительной его части), оставившего каменноящечный могильник. Соответственно, артефакты (элементы защитного и наступательного вооружения), сопровождающие погребенных, в значительной степени также представляются импортами. Публикуемая коллекция наконечников копий, содержащая небольшое разнообразие типов, позволяет считать Келийский могильник опорным памятником для типологии наконечников копий Северного Кавказа XIII-XIV веков.

Ключевые слова: Высокогорная Ингушетия, Келийский могильник, каменные ящики, золотоордынское время, наконечники копий, военное дело.

Цитирование. Гаглойты Р. Х., Кочкаров У. Ю., Мамаев Р. Х., Нарожный В. Е., Нарожный Е. И., 2021. Наконечники копий келийского каменноящечного могильника (Горная Ингушетия) // Нижневолжский археологический вестник. Т. 20, № 2. С. 169-185. DOI: https://doi.org/10.15688/nav.jvolsu.2021.2.8

Большинство публикуемых археологических материалов вводятся в научный оборот впервые - это находки наконечников копий из погребений Келийского каменноящечного могильника (ныне - Джейраховский район Республики Ингушетия), исследовавшегося в 1987-1988 гг. в связи с началом трассировки полотна подъездной автодороги через Горно-Ассиновскую котловину к планировавшемуся тогда тоннелю сквозь подножие Главного Кавказского хребта. По проекту строительство Кавказской перевальной железной дороги (КПЖД) должно было соединить Северный Кавказ с соседней Грузией и всем Закавказьем в целом [Нарожный В.Е., Нарожный Е.И., 2011; Нарожный Е.И., Мамаев, 2018]. В 1987 г. трассировкой маршрута подъездной автодороги почти по средней части обширного некрополя был частично задет Келийский могильник, состоявший из каменных ящиков ${ }^{2}$, грунтовых захоронений ${ }^{3}$ и полуподземных склепов ${ }^{4}$ [Нарожный Е.И. и др., 1990; Чахкиев, 1986; Чахкиев, 1987; Чахкиев, 2019, с. 48-57]. Некоторые из публикуемых артефактов уже введены в научный оборот [Виноградов, Нарожный, 1994; Басов и др., 2003; Нарожный В.Е., Нарожный Е.И., 2012, c. 194, рис. 3,2; Нарожный В.Е. и др., 2005; Нарожный В.Е., 2014; Нарожный Е.И. и др., 2017, с. 166-176; и др.].

Раскопанная часть Келийского могильника, учитывая наличие значительного количества коллективных захоронений каменноящечного некрополя и 12 полуподземных склепов, в 1987-1988 гг. дала разнообразные археологические материалы, так или иначе связанные почти с 1 тыс. погребенных [Нарожный В.Е., 2004]. Объем собранных сведений и материалов позволяет не только производить статистические расчеты, но и попытаться выявить и реконструировать прижизненные «профессии» погребенной части населения гор- 
ноингушского общества золотоордынского времени, оставившего Келийский могильник.

Важность этот материал представляет и по другим причинам: датированный медными и серебряными монетами (хотя и пробитыми) Золотой Орды, Хулагуидов, Русудан и грузино-хулагуидскими, могильник расположен на территории, так и не вошедшей в сферу прямого политико-экономического диктата Золотой Орды [Виноградов, Нарожный, 1988; Нарожный Е.И., Нарожная, 2011, с. 190 194; Нарожный Е.И., Нарожная, 2012]. Тем не менее полученные здесь многочисленные и разнообразные артефакты, включая и различные категории предметов средневекового вооружения горцев, вне всякого сомнения демонстрируют как географию поступления оружейных «импортов» из окружающего их мира, так и экземпляров, изготовленных по их образцам местными мастерами. Это открывает хорошие перспективы в области изучения различных сторон организации военного дела горцев Восточного Придарьялья в контексте их перманентных, но не всегда однозначных взаимоотношений с кочевым и городским (округа Татартупа) населением Золотой Орды и соседней Грузии, оказавшейся в зависимости от династии Хулагуидов [Нарожный Е.И. и др., 2017; Мужухоев и др., 2017; Мамаев, Кочкаров, 2020; Нарожный В.Е., Нарожный Е.И., 2008; Нарожный В.Е., Нарожный Е.И., 2009; Нарожный В.Е., Нарожный Е.И., 2021].

Ниже мы приводим сведения о 20 наконечниках копий и 1 втоке, обнаруженных при раскопках каменных ящиков и грунтовых погребений Келийского могильника. В их число входят 2 наконечника копья из погребений, исследованных М.Б. Мужухоевым ${ }^{5}, 18{ }^{6}$ наконечников копий и 1 вток из раскопок Е.И. Нарожного [Мужухоев, 1988; Нарожный Е.И., 1989].

Наконечник из погребения 5 (рис. 1,1).

Погребение представляет собой грунтовое захоронение, «отмеченное» вертикально стоящим камнем и содержащее кости как минимум 3 индивидов. Отдельные камни, артефакты и кости, расположенные хаотично, создают впечатление разрушенного и перекопанного погребения, представляющего имитацию (выполняемую обычно из нескольких камней в изголовье) классического для данного могильника типа каменного ящика.
С другой стороны, это может быть перезахоронение «на стороне» старых останков, вынутых из каменного ящика при подготовке нового захоронения. Однако обычно в таких случаях костные останки и артефакты лежат более кучно, собранные в так называемые пакеты, не говоря уже о том, что в подавляющем количестве случаев они остаются либо в самом каменном ящике, либо на плитах его перекрытия.

Наконечник представляет собой крупный образец общей длиной 48 см, имеет листовидную форму пера, линзовидную в сечении с выраженным ребром жесткости, длиной $26 \mathrm{~cm}$ и шириной 4,8 см. Плечики пера плавные и переходят в вытянуто-коническую втулку (длина 22 см, ширина 5 см), свернутую из толстого листа (место соединения четко просматривается) [Нарожный Е.И., 1989, с. 12, 13, рис. 15-16].

Наконечник из погребения 15 (рис. 1,9).

Погребение представляло собой навал камней - прежде всего «плиты перекрытия» без боковых стенок, на, под и между которыми были разбросаны кости и инвентарь нескольких (точное количество установить не удалось) погребенных как мужского, так и женского пола.

Видимо, погребение было разрушено, но на его месте не зафиксировано ни подзахоронения нового погребенного, ни перезахоронения старых останков. Разрушенные могилы встречаются на данном памятнике нередко (например, предыдущее погребение № 5).

От наконечника осталась только коническая втулка, сохранившаяся почти полностью (длина 7,2 см, ширина 2,8 см). К сожалению, втулка отломана до начала пера, поэтому форму пера определить невозможно. Однако, если чертеж верен, то в верхней части втулка из конической переходит в цилиндрическую, а общая пропорция между длиной втулки и шириной нижнего и верхнего отверстий характерна именно для типа наконечников с плоским пером.

Помимо втулки от наконечника копья здесь же присутствовали и другие находки целых и фрагментированных образцов наступательного и защитного вооружения. Самым интересным для нас (в рамках данной публикации) является фрагмент «обоюдоост- 
рого острия сабли» длиной 40 см и шириной 6 см (толщина спинки указана в 1 см, хотя у острия с двусторонней заточкой «спинки» быть не может). Вероятность того, что «острие сабли» могло быть утраченным пером наконечника, есть, правда его длина и ширина чрезвычайно велики (по крайней мере в сравнении с остальными наконечниками, известными на этом могильнике).

Наиболее вероятно, что данный фрагмент, скорее всего, является частью меча (довольно редкого типа оружия среди образцов, обнаруженных на этом могильнике), поскольку для острия сабли он слишком широк, к тому же на чертеже он, скорее, похож на острие клинкового оружия с прямым клинком. К сожалению, проверить все предположения можно было бы только при изучении самого артефакта, что невозможно в силу утраты части археологических коллекций (в том числе и материалов Келийского могильника), хранящихся в Национальном музее Чеченской Республики, о чем было указано выше.

В этом же погребении содержались многочисленные фрагменты железной кольчуги, наконечник стрелы и сабля с практически прямым лезвием, перекрестием с шаровидными, опущенными к клинку концами, с обломанными острием и навершием рукояти [Нарожный Е.И., 1989, с. 20, 21, рис. 40, 41].

Это погребение уже публиковалось, причем из-за того, что сабля и обломанное острие сабли опубликованы так же, как на чертеже в отчете, произошел казус, сделавший саблю из погребения 15 Келийского могильника одной из самых длинных сабель на Северном Кавказе (около 132 см).

Наконечник из погребения 22 (рис. 2,2).

Отождествление данного наконечника с погребением 22 основано на подписи к рисунку 209а, на котором изображена данная находка, но на чертеже погребения и в описании его инвентаря нет сведений о данном артефакте.

Погребение 22 представляет собой длинный (3,7 м) каменный ящик, содержащий последнее по времени подзахоронение ребенка (лежащего вытянуто, в анатомическом порядке) и кости еще 4 погребенных, собранных в три навала. Среди них кости только одного взрослого человека.
На плитах погребения 22 находилось погребение 21, которое, без сомнения, представляло собой переотложенные кости и инвентарь из этого каменного ящика.

Несмотря на то что на фотографиях, чертежах и в описании этого погребения не было наконечника копья, оно содержало атрибуты воинского погребения: два фрагмента железных предметов, интерпретируемых как крепления ножен сабли и фрагмент железной крупной пластины, похожий на фрагмент шлема. Данная интерпретация довольно условна ввиду отсутствия возможности ознакомиться с оригиналами, но это практически единственное свидетельство в пользу того, что в каменном ящике 22 находилось воинское погребение, позже перемещенное на перекрытие погребального сооружения и получившее обозначение как погребение 21.

Однако это не объясняет того, почему при расчистке обоих погребений наконечник копья не был зафиксирован и в дальнейшем включен в инвентарь погребения 22.

Наконечник копья (общая длина 43 см) имел очень длинное (32 см) граненое (ромбовидное в сечении, шириной 1,8 см) острие, переходящее с помощью коротких плечиков в узкую конусовидную втулку (длиной $11 \mathrm{~cm}$ ), расширяющуюся до 2,7 см. Ближе к нижнему концу втулки сохранился гвоздь с выпуклой шляпкой для фиксации наконечника на древке [Нарожный Е.И., 1989, с. 25, 26, рис. 209a,2].

Наконечник из неизвестного погребения (рис. 2,1).

Наконечник, как и копье из погребения 22, присутствует только на рисунке 209а, но в отличие от предыдущего артефакта не указан в подписи к рисунку. Ни в тексте отчета, ни в иллюстрациях сведений о нем обнаружить не удалось.

Тем не менее по факту своего наличия он должен быть проанализирован. К тому же он является самым крупным (длина 45 см) из наконечников с граненым (ромбовидным в сечении, шириной 1,4 см) острием (длина 37 см), которое плавно (плечики отсутствуют) переходит в цилиндрическо-коническую (слегка расширяющуюся до 2,4 см) втулку длиной 8 см. Копье фиксировалось на древке с помощью гвоздя, сохранившегося около нижнего окончания втулки, имеющего кольцевидное 
навершие [Нарожный Е.И., 1989, с. 25, 26, рис. 209a,3].

Наконечник из погребения 32 (рис. 2,6).

Погребение представляло собой каменный ящик, состоящий из вертикально установленных плит, боковых и торцевых стенок и горизонтально уложенных на них плит перекрытия.

Могильное сооружение отличается от классического для этого памятника типа погребений своими размерами - удвоенной длиной боковых стенок (4 м), вытянутых по оси 3 - В, при стандартной ширине, варьирующейся от 0,8 м до 0,3 м. Это объясняется тем, что в погребении было обнаружено 4 погребенных, двое из которых лежали в вытянутом положении головами на 3 в западном и восточном концах погребения. Между ними находилось два переотложенных скопления костей, в одном из которых (в ногах у «западного» погребенного, судя по инвентарю - женщины) и находился наконечник копья длиной 24,6 см с узким граненым (ромбовидным в сечении) острием (длиной - 14,6 cм, шириной 1 см), переходящим в довольно длинную конусовидную втулку (длина - 10 см, ширина 3,5 см) с узким, отогнутым по краю венчиком.

К этому же погребенному, видимо, относятся и 5 железных черешковых наконечников стрел [Мужухоев, 1988, с. 27-29, рис. 136, 151].

Наконечник из погребения 45 (рис. 1,8).

Погребение представляет собой «правильный» (длиной 2 м и шириной 0,8 м) каменный ящик, в котором, судя по инвентарю, была погребена женщина.

На плитах перекрытия были зафиксированы переотложенные разрозненные костные останки двух погребенных, которые, судя по разнообразному инвентарю (в том числе наконечнику копья), представляли собой мужское и женское погребения, находившиеся в этом каменном ящике до помещения туда последней погребенной (обнаруженной in situ).

Наконечник копья длиной 27 см имеет вытянуто-треугольное (плоское в сечении) перо (длиной 14 см и шириной 2,9 см) с закругленным (обломанным или сточенным) острием с выраженными плечиками, переходящими под тупым углом (около 45 градусов) в узкую, плавно расширяющуюся втулку (длиной 13 см и шириной 2,6 см).
К этому же мужскому погребению относились и другие, не менее интересные находки: 3 наконечника железных черешковых стрел, обломки щита и перекрестие сабли с опущенными концами [Мужухоев, 1988, с. 4344 , рис. 136,213$]$.

Наконечник из погребения 69 (рис. 2,3).

Погребение представляет собой классический каменный ящик (длиной 2,2 м и шириной 0,75 м, ориентированный по оси $3-$ В), закрытый плитами перекрытия и содержащий останки двух погребенных. Первоначальное погребение, судя по инвентарю, было женским и сложено в виде навала костей в изголовье ящика. Потом в этот же ящик был подзахоронен мужчина, между берцовыми костями правой ноги которого и стенкой острием к ступням находился наконечник копья.

Наконечник копья длиной 33 см имел граненое острие (ромбовидной в сечении формы, шириной 1,1 см) с четко выраженными плечиками, переходящими в узкий конец конической втулки (длиной $11 \mathrm{~cm}$ ) и расширяющимися в конце до 3,6 см. Нижняя часть втулки усилена широким ободом, в котором находился гвоздь для фиксации наконечника на древке [Нарожный Е.И., 1989, с. 60, 61, рис. 209a, 1, 210].

Наконечник из погребения 84 (рис. 1,Ø).

Погребение представляло собой переотложенный навал костей и погребального инвентаря, лежащего на плитах перекрытия классического каменного ящика (погребение 85).

Наконечник копья (общая длина $21 \mathrm{~cm}$ ) состоял из линзовидного в сечении пера длиной 9,6 см, подтреугольного в профиле (шириной 2,6 см), с покатыми плечами, переходящими в длинную $(11,4$ см), слегка расширяющуюся (ширина 2,6 см) втулку.

Помимо наконечника копья, на плитах перекрытия каменного ящика находился целый шлем, навершие, перекрестие (с опущенными шаровидными концами) и фрагмент клинка сабли, наконечники стрел (среди которых выделяется плоский в сечении с крестообразными вырезами) [Нарожный Е.И., 1989, с. 69 , рис. 259-263].

Наконечник и втулка копий из погребения 99 (рис. 1,5).

Погребение представляет собой нижний ярус двухъярусного каменного ящика, когда 
прямо на плитах перекрытия 99-го погребения возвели стенки нового, 97-го, с помощью вертикальных плит, перекрытых, в свою очередь, горизонтальными сверху.

В 99-м ящике погребено два человека, первый из которых, изначально погребенный в этом ящике, представлен навалом из костей, собранных в ногах (у восточной стенки), и сопровождается мужским инвентарем - втулкой от наконечника копья с основанием обломанного пера и наконечником стрелы.

Втулка цилиндрическо-конической формы (длина 9 см) слегка расширяется до 2,6 см. Хорошо просматривается сведенный шов. У нижнего края есть гвоздь, фиксировавший наконечник на древке. Сохранилось одно из плечиков пера.

Второй погребенный в 99-м каменном ящике, подзахороненный к первому, лежал вытянуто на спине. Длина костяка составляет 150 см. Возраст - 30-35 лет. Справа от него на уровне локтя острием к голове лежал наконечник копья.

Наконечник копья (длиной 26,5 см) состоит из пера (линзовидного в сечении) длиной 15 см и шириной 3,3 см, переходящего через очень короткие плечики в коническую втулку длиной 11,5 см и шириной 3 см. Размеры приводятся по описанию погребения и инвентаря, хотя следует уточнить, что в отчете приведены два чертежа одного и того же наконечника копья, отличающиеся друг от друга настолько, что могли быть приняты за разные экземпляры. В нашей работе мы используем более качественный и точный чертеж, изображенный на рис. $114 \mathrm{a}, 4$. От древка остался тлен длиной 0,82 м [Нарожный Е.И., 1989 , с. $74-75$, рис. $312,313,114 \mathrm{a}, 4]$.

Наконечники двух копий из погребения 132 (рис. 1,2, 2,4).

Погребение представляет компактно переотложенные кости двух человек (судя по инвентарю, мужчины и женщины), изначально помещенные в нижележащий каменный ящик 133 и перемещенные над перекрытием этого ящика вследствие необходимости подзахоронения нового индивида.

Наконечник первого копья (длиной 39 см) имел уплощенное перо длиной 25 см, но с выраженным ребром жесткости (сечение пера линзовидное, ширина 3,4 см). Вытянуто-треу- гольный профиль пера дополняется короткими плечиками, преходящими под тупым углом в цилиндрическо-коническую втулку (длина 14 см, ширина 3 см).

Наконечник второго копья из этого погребения (длина 25 см) имел граненое острие длиной 13,8 см и шириной 1 см, переходящее через очень маленькие плечики в коническую втулку (длиной 11,2 см), расширяющуюся до 2,8 см.

Помимо наконечников копий, в этих же материалах содержался и другой воинский инвентарь: железный шлем, пять наконечников стрел и окончание (бутероль) ножен сабли [Нарожный Е.И., 1989, с. 74-75, рис. 417420 , рис. $114 \mathrm{a}, 1,1146,1]$.

Наконечник копья из погребения 183 (рис. 1,4).

Погребение представляет собой типичный каменный ящик, ориентированный по оси 3 - В и содержащий кости одного человека. При длине ящика в 180 см длина находящегося там костяка составляла 135 см. Возраст погребенного определяется в $18-20$ лет.

Наконечник (длина 27,3 см) представляет собой небольшое по длине (10,2 см) и ширине (2,4 см) перо, уплощенно-ромбовидное в сечении с выраженным ребром жесткости, переходящее в длинную $(17,1$ см) втулку цилиндрическо-конической формы, расширяющуюся до 2,4 см. Во втулке остался фрагмент древка, а также сохранился деревянный тлен от древка копья длиной 0,6 м.

Этот наконечник изображен в отчете дважды, причем рисунки несколько отличаются. Один из вариантов уже был приведен в статье Е.И. Нарожного, Д.Ю. Чахкиева [Нарожный Е.И. и др., 2017]. В нашей работе мы приведем второй рисунок с рис. 114a,3, поскольку на этой же иллюстрации находятся и три других наконечника копья [Нарожный Е.И., 1989, с. 134-135, рис. 562-566, рис. $114 \mathrm{a}, 1,1146,1]$.

Наконечник копья из погребения 185 (рис. 2,7).

Погребение 185 представляет собой западную часть длинного каменного ящика (2,5 м), разделенного поперечным перекрытием на два погребения (185 и 186) и ориентированного по оси 3 - В. В погребении 185 нахо- 
дился костяк подростка, лежавшего вытянуто на спине. Слева от черепа, острием к ногам, найден наконечник копья длиной 24,5 см с граненым, ромбовидным в сечении острием (длина 16,3 см, ширина 1,4), слегка утолщающимся в средней части и переходящим в короткую $(8,2$ см) коническую втулку с обломанным нижним краем (ширина 2,6 см) [Нарожный Е.И., 1989, с. 135-136, рис. 571, 574].

Наконечник копья из погребения 186 (рис. 2,5).

Ко второму (186-му) из этой же пары погребений относится еще один наконечник копья, изображенный на рис. 114б,2, но, к сожалению, информации о нем ни в описании инвентаря 186-го погребения, ни в иллюстрациях не содержится.

Само погребение 186, по мнению Е.И. Нарожного, было первым, после чего оно было достроено к западу и отделено от погребения 185 поперечной стенкой. Костяк погребенного из погребения 186 был смещен к востоку.

Сам наконечник длиной 24,7 см представляет собой узкое граненое острие длиной 11,6 см и шириной 1,5 см, переходящее через короткие плечики в широкую конусовидную втулку длиной 13,1 , шириной 3,3 см.

В этом же погребении находилась сабля с деталями ножен [Нарожный Е.И., 1989, с. $136-137$, рис. $571,574,1146,2]$. (рис. 2,8).

Наконечник копья из погребения 198

Данный наконечник соотнесен с погребением 198 на основании подписи к рисунку 1146,3 , но в описании и иллюстрациях как самого погребения, так и его инвентаря этот наконечник не упоминается. К тому же погребение представляет собой небольшой детский каменный ящик длиной всего 0,9 м.

Наконечник (длиной 22,6 см) представляет собой длинное (14,7 см), средней ширины (1,7 см), граненое, в форме уплощенного ромба, острие, переходящее через выраженные плечики (под углом в 45 градусов) в короткую коническую втулку длиной 7,9 см, обломанную по нижнему краю, ее восстанавливаемый диаметр - 2,1 см. Не смотря на то что это детское погребение, здесь фиксируется также обломок острия сабли [Нарожный Е.И., 1989, с. 145-146, рис. 616, $617,1146,2]$.
Наконечник копья из погребения 225 (рис. 2,10).

Погребение представляло собой переотложенные кости двух индивидов и инвентарь из каменного ящика 226, находящегося под погребением 225.

Небольшой наконечник (длиной 17,8 см) с длинным (13,8 см), узким (1,2 см) и плавно сужающимся к концу граненым, ромбовидным в сечении, острием переходит через небольшие плечики в короткую (4 cм) усеченно-конусовидную втулку шириной 1,5см.

Кроме того, в погребении содержались 4 наконечника стрел и нож, предположительно переделанный из клинка сабли [Нарожный Е.И., 1989, с. 161-162, рис. 707-710].

Наконечник из погребения 226 (рис. 1,3).

Погребение - длинный $(2,4$ м) каменный ящик, содержащий костяк одного погребенного (длина костяка 165 см), лежащего вытянуто на спине. Справа, на уровне плечевой кости погребенного, лежал наконечник копья.

Сам наконечник (длиной 36,4 см) имел длинное $(22,4$ см), уплощенное и широкое (3,9 см) перо с ребром жесткости, переходящее через выраженные плечики в вытянутоконическую втулку длиной 14 см и шириной 3,5 см. Тлен от древка прослеживался на длину $0,75 \mathrm{M}$.

В этом же погребении содержались остатки берестяного колчана с шестью наконечниками стрел [Нарожный Е.И., 1989, с. 162, рис. 714-718, 1146,2].

Наконечник из погребения 236 (рис. 1,7).

Погребение представляет собой каменный ящик длиной 2,2 м с погребением одного индивида, лежащего вытянуто на спине (длина костяка 1,6 м). Слева от погребенного, на уровне таза, обнаружен наконечник копья.

Сам наконечник небольшого размера (длина 19,2 см), имеющий треугольное в профиле (длиной 11,7 см и шириной 2,7 см), уплощенное, с ребром жесткости перо, острие которого закруглено, видимо, в результате стачивания. Перо имеет четко выраженные плечики, переходящие к усеченно-конической втулке длиной 7,5 см и шириной 2,1 см.

Необходимо отметить, что в иллюстрации к отчету с изображением копья допущена 
ошибка в указании масштаба наконечника в два раза больше по сравнению с реальным размером [Нарожный Е.И., 1989, с. 166-167, рис. 736-739].

\section{Наконечник копья и вток из погре-} бения 243 (рис. 2,9,11).

Погребение 243 представляет собой небольшой (длиной 0,8 м) западный отсек каменного ящика общей длиной 2,1 м. В «отсеке» собраны переотложенные кости и инвентарь ранее погребенных индивидов (мужского и женского), смещенные и отгороженные от восточной части ящика в результате подзахоронения сюда нового погребенного.

Наконечник копья длиной 24 см имеет длинное (18,3 cм) и узкое (1 см) граненое, ромбовидное в сечении, острие, погнутое на конце и переходящее без плечиков в короткую (5,7 см) коническую (ширина 1,9 см) втулку.

Вток представлял собой полую цилиндрическо-коническую втулку длиной 10,6 cм, усиленную на нижнем (шириной 2,8 см) конце широкой полосой железа, также дополнительно снабженную гвоздем для фиксации на деревянном древке [Нарожный Е.И., 1989, c. $172-173$, рис. $753-755]$.

Необходимо отметить, что мы сознательно не публикуем в этой работе наконечники копий, обнаруженные в коллективных полуподземных усыпальницах данного могильника, в первую очередь по причине того, что их невозможно соотнести с определенными захоронениями ввиду коллективного характера склеповых погребений. Во-вторых, поскольку считаем, что население, хоронившее своих умерших в каменных ящиках, может являться инокультурным ${ }^{7}$ (в различных, в том числе самых широких толкованиях этого слова) по отношению к коренному горноингушскому населению, хоронившему своих мертвых в родовых коллективных склепах, расположенных здесь же. Это бы вынудило нас рассматривать данную категорию гораздо шире - с привлечением находок других склеповых могильников Горной Ингушетии и Чечни, что невозможно из-за ограниченности объема работы.

В данном контексте находки вооружения (в том числе копий) могут являться маркерами как другой погребальной обрядности, принадлежащей группе людей, оставившей мо- гильник, образцами, демонстрирующими отличные от местной технику и технологии изготовления холодного оружия ${ }^{8}$, так и демонстрировать принадлежность погребенных в каменных ящиках Келийского могильника к военной традиции, способам, методам и техникам применения вооружения, сформировавшихся в другой географической и исторической ситуации.

Это возможно на основе учета и анализа всех сведений не только о самом артефакте (исходя из морфологического и функционального анализа его формы), но и в сочетании последнего с другими предметами погребального инвентаря из комплекса наступательного и защитного вооружения, что дополнительно даст возможность реконструировать воинскую ${ }^{9}$ «специализацию» погребенных. В рамках изучения воинской «специализации» мы приводим и сведения о росте погребенных ${ }^{10}$. Это важно в тех случаях, когда был зафиксирован тлен от древка копья, в связи с небольшой длиной которого они были интерпретированы как дротики [Нарожний Е.И. и др., 2017]. Отмечая небольшие размеры наконечников и длины тлена от древка последних, мы оставляем вопрос открытым, заметив, что в данную подборку не попали небольшие втульчатые наконечники, интерпретируемые сейчас как боевая часть метательных дротиков, хотя во время написания отчета они определялись как наконечники стрел.

«Грунтовые» погребения во всех вышеприведенных случаях ${ }^{11}$ являются переотложенными погребениями из нижерасположенных каменных ящиков. Перемещение костей и инвентаря, видимо, происходило, когда в уже существующее погребение необходимо было поместить другого человека, который, скорее всего, являлся близким родственником (членом малой семьи) первого погребенного.

Кости первоначально погребенного и сопровождающий его инвентарь могли оставляться и внутри ящика. Тогда они обычно просто сгребались в кучу и сдвигались к одной из торцевых стенок ящика, обычно к ногам. Если стандартной длины (около 2 м) ящика не хватало для того, чтобы уместить нового погребенного в освобожденное от костей пространство, то ящик мог достраиваться с одной из торцевых сторон. 
В длинных ящиках, достигающих иногда удвоенной (до 4 м) длины, фиксируется до двух погребенных, лежащих вытянуто на спине по тандемной схеме с расположенными между ними и/или в концах ящика переотложенными костями и инвентарем еще нескольких (до 4) индивидов ${ }^{12}$.

Замечено, что ящик не всегда достраивали в длину по причине примыкания к нему других погребений (видимо, из-за этого достраивание ящика в ширину также было невозможным). В этом случае истлевшие останки (и инвентарь) ранее умершего вынимались из погребения и после положения свежего трупа в могилу и закрывания его плитами перекрытия раскладывались на этих плитах, а иногда, после засыпания ящика землей, и несколько выше. Именно это привело к появлению «грунтовых» погребений, под которыми во всех случаях фиксировались каменные ящики. «Грунтовые» погребения во всех случаях оказались переотложенными «пакетами» костей и вещей, часто несколько разбросанных по всей площади погребальной ямы.

В нескольких случаях авторами раскопок были зафиксированы двухъярусные каменные ящики, когда прямо на плитах погребения устанавливались вертикальные плиты стенок, перекрытые впоследствии горизонтальными. В этом случае на обоих «этажах» располагались лежащие in situ вытянуто на спине костяки, которые могли сопровождаться переотложенными, сдвинутыми костяками других погребенных. Это было вызвано, по-видимому, теми же причинами, что и нахождение двух погребенных, лежащих «тандемно» в длинных каменных ящиках.

Вышеприведенная информация о погребениях в каменных ящиках Келийского могильника, содержащих наконечники копий, продолжает серию работ, посвященных древковому, клинковому и защитному вооружению золотоордынского населения Горной Ингушетии. Введение в научный оборот сведений о наконечниках копий XIII-XIV вв. подтверждает статус каменноящечного могильника Кели как опорного для этой категории археологических объектов всего Северного Кавказа ввиду его исследованности в результате стационарных археологических раскопок. Не менее важно, что данный памятник отра- жает непростую ситуацию, сложившуюся в горной части Северного Кавказа в XIII$\mathrm{XIV}$ веках. Анализ и публикация результатов его раскопок в 1987-1988 гг. расширяет источниковую базу, стимулирующую к поиску новых решений, проливающих свет на белые пятна его истории.

Представленные выше наконечники копий логично разделить на два типа по форме пера.

Наконечники копий из погребений № 5 , $45,84,99,132,183,226,236$ имеют уплощенное перо. При этом большинство из них $(5,99$, $132,183,226,236)$ имеют и четкие ребра жесткости, хотя два наконечника из погребений № 45 и 84 имеют плоское перо, утончающееся к краю.

Копья с плоским пером можно разделить по форме профиля пера: № 5 имеет уникальную листовидную (элипсовидную форму пера), в то время как все остальные наконечники с плоским пером, как с ребром жесткости, так и без него, а именно из погребений № 45,84 , $99,132,183,226,236$, имеют треугольный профиль пера, когда наибольшая ширина острия достигается на уровне плечиков и оттуда постепенно сужается к острию.

К этому же типу плоских наконечников относятся и две втулки из погребений № 15 и 99, которые по вышеизложенным причинам, скорее всего, являются частью копий с уплощенным пером.

К типу наконечников копий с граненым острием относятся артефакты из погребений № $22,32,69,132,185,186,198,225,243$, н/и (неизвестного погребения).

По пропорциям ромбовидного сечения можно разделить артефакты на тип наконечника с граненым острием, толщина и ширина которого примерно равна (№ 32, 69, 132, 186, 225 , 243, н/и), и те, у которых ширина приблизительно в 2 раза больше толщины (№ 22, 185, 198).

С другой стороны, наконечники с ромбовидным сечением острия из погребений № 22, 32, 69, 132, 186, 198, 225 отличаются по наличию плечиков, оформляющих переход от острия к втулке и, скорее всего, свидетельствующих о наличии у них круглой в сечении монолитной шейки, отделяющей острие от втулки, в то время как у наконечников из погребений под неизвестным номером, 185, 243 нет ни плечиков, ни переходной шейки. 
Все погребения в каменных ящиках Келийского могильника, благодаря многочисленному и выразительному материалу (в том числе нумизматическому), датируются XIII-XIV вв., что делает их сравнение с существующими типологиями наконечников копий Северного Кавказа не совсем корректным, так как типологии Д.Ю. Чахкиева, В.А. Каминского, У.Ю. Кочкарова и А.А. Сланова кроме того, что включают материалы продолжительного хронологического периода, еще и охватывают большую географию памятников, включающих не только погребения, но и бытовые памятники, святилища и случайные находки [Чахкиев, 2019; Каминский, 1992; Кочкаров, 2008; Сланов, 2007].

По этой причине (а главное - из-за ограниченности объема, доступного для публикации) определение места наконечников копий в существующих типологиях смежных территорий Северного Кавказа будет предметом отдельной статьи.

В типологии позднесредневековых копий (и дротиков), разработанной Д.Ю. Чахкиевым еще в 1986 г., имеется группа Б, тип 1, к которой относятся граненые наконечники из Кели [Чахкиев, 2019]. Но она составлена раньше раскопок Келийского могильника. Кроме того, эта группа включала всего 18 экземпляров (из которых только 9 были наконечниками копий и столько же наконечников дротиков), содержала находки, относящиеся к различным отрезкам позднего средневековья, не говоря уже о том, что по крайней мере одна находка из Ярыш-Марды имеет высокую вероятность отношения к раннему средневековью [Нарожный Е.И., 2003].

Уже введенные и вводимая (датируемая XIII-XIV вв.) в научный оборот коллекции наконечников копий Келийского могильника позволяют считать его опорным памятником для изучения наступательного и защитного вооружения Северного Кавказа.

\section{ПРИМЕЧАНИЯ}

${ }^{1}$ Работа выполнена при поддержке гранта РФФИ 20-59-07002.

Search is prepared by support of RFFS grant 20-59-07002
${ }^{2}$ Каменные ящики, вытянутые с востока на запад, содержали внутри как индивидуальные, так и коллективные погребения. Последние, как правило, представлены трупоположением in situ, рядом с которыми у восточной или у западной стенки ящика были сложены скелеты без определенной системы в виде близко расположенных друг к другу навалов костей (до 6 скоплений), хаотично сдвинутых вместе с погребальным инвентарем.

${ }^{3}$ Обычно представляли собой нагромождения костных остатков от одного до нескольких, нередко неполных, скелетов с инвентарем и без него.

${ }^{4}$ Специфичной особенностью являлось то, что склепы эти устраивались под массивными валунами, вероятно скатывавшимися с вершины скалистого массива Цей-Лам, возвышающегося над округой, к его подножию, где и был обустроен Келийский могильник XIII-XIV веков.

5 Учитывая различные номера погребений из раскопов М.Б. Мужухоева и Е.И. Нарожного, в которых обнаружены копья, мы приводим их в общей последовательности, дополнительно указывая в тексте авторов материалов.

${ }^{6}$ В том числе две втулки с обломанным пером.

${ }^{7}$ Интерпретация этого факта вызывает дискуссии как среди авторов данной статьи, так и среди других исследователей, тем более что основой для представления об «инаковости» погребенных в Келийском каменноящечном могильнике служит обильный погребальный инвентарь (помимо образцов вооружения), не вошедший в нашу публикацию ввиду ограниченности ее объема.

${ }^{8}$ В дальнейшем мы попытаемся провести исследования сохранившихся образцов, в первую очередь металлографическими методами. К сожалению, большая часть находок пропала из Чечено-Ингушского краеведческого музея [Мамаев, Дачаев, 2017].

${ }^{9}$ Специализация может быть обусловлена также имущественной и возрастной градацией.

${ }^{10}$ Вернее, костяка, в том случае, когда он сохранился in situ в вытянутом положении и был зафиксирован в отчете.

${ }^{11}$ Скорее всего, данное заключение справедливо и для всего могильника в целом, который еще не проанализирован целиком ввиду больших объемов проведенных работ.

${ }^{12}$ Фиксация двух погребенных in situ (вытянуто на спине) внутри одного ящика, который для этого, видимо, удлинялся, могло происходить в результате одновременной смерти двух членов одной семьи, а также в том случае, когда тело ранее погребенного в каменном ящике не успевало потерять все органические соединительные ткани. На Келийском каменноящечном могильнике не зафиксировано ни одного переотложенного погребения, сохранившего антропологическую целостность. 


\section{ПРИЛОЖЕНИЯ}

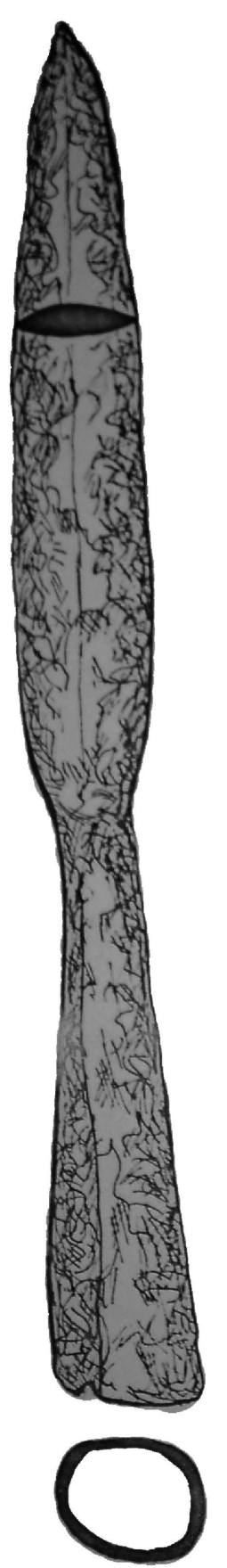

1
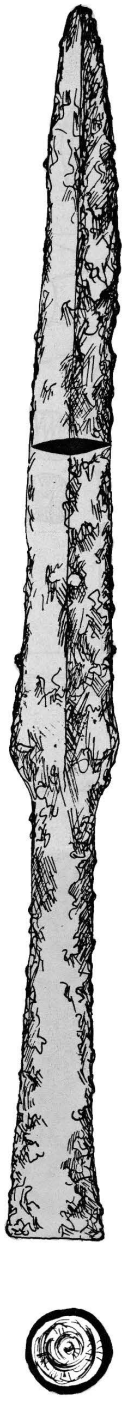

2

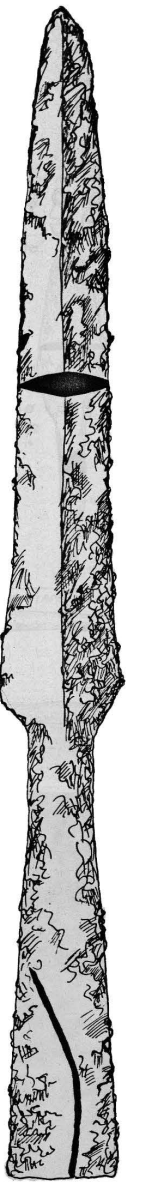

0

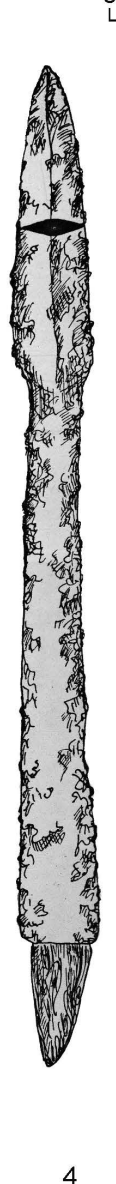

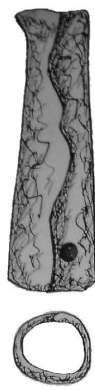

10

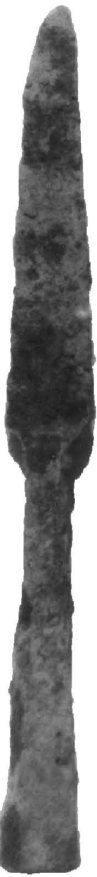

8
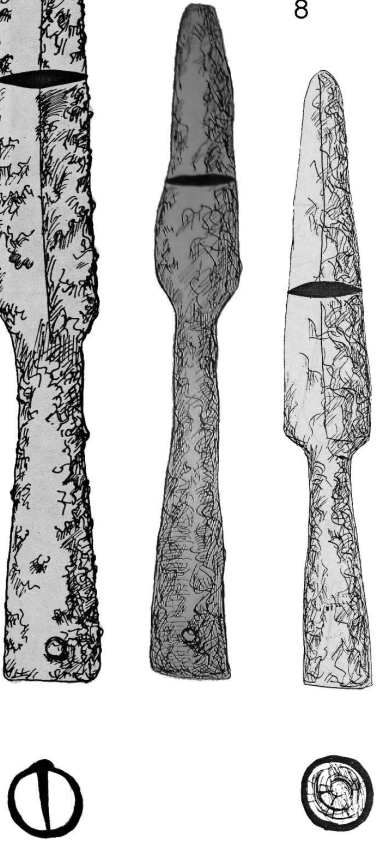

7

Рис. 1. Наконечники копий из погребений Келийского могильника XIII-XIV вв. Высокогорной Ингушетии (1-7, 9-10 по: [Нарожный Е.И., 1989], 8 - по: [Мужухоев, 1988]):

1 - погр. 5; 2 - погр. 132; 3 - погр. 226; 4 - погр. 183; 5, 10 - погр. 99; 6 - погр. 84; 7 - погр. 236; 8 - погр. 45; 9 - погр. 15

Fig. 1. Spearheads of the Keliysky burial ground of the $13^{\text {th }}-14^{\text {th }}$ centuries AD from Highland Ingushetia (1-7, 9-10 after: [Narozhnyy E.I., 1989], 8 - after: [Muzhukhoev, 1988]):

1 - burial 5; 2 - burial 132;3 - burial 226; 4 - burial 183; 5, 10 - burial 99; 6 - burial 84; 7- burial 236; 8 - burial $45 ; 9$ - burial 15 


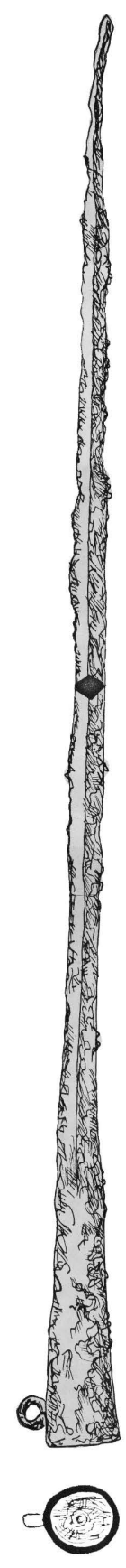

1
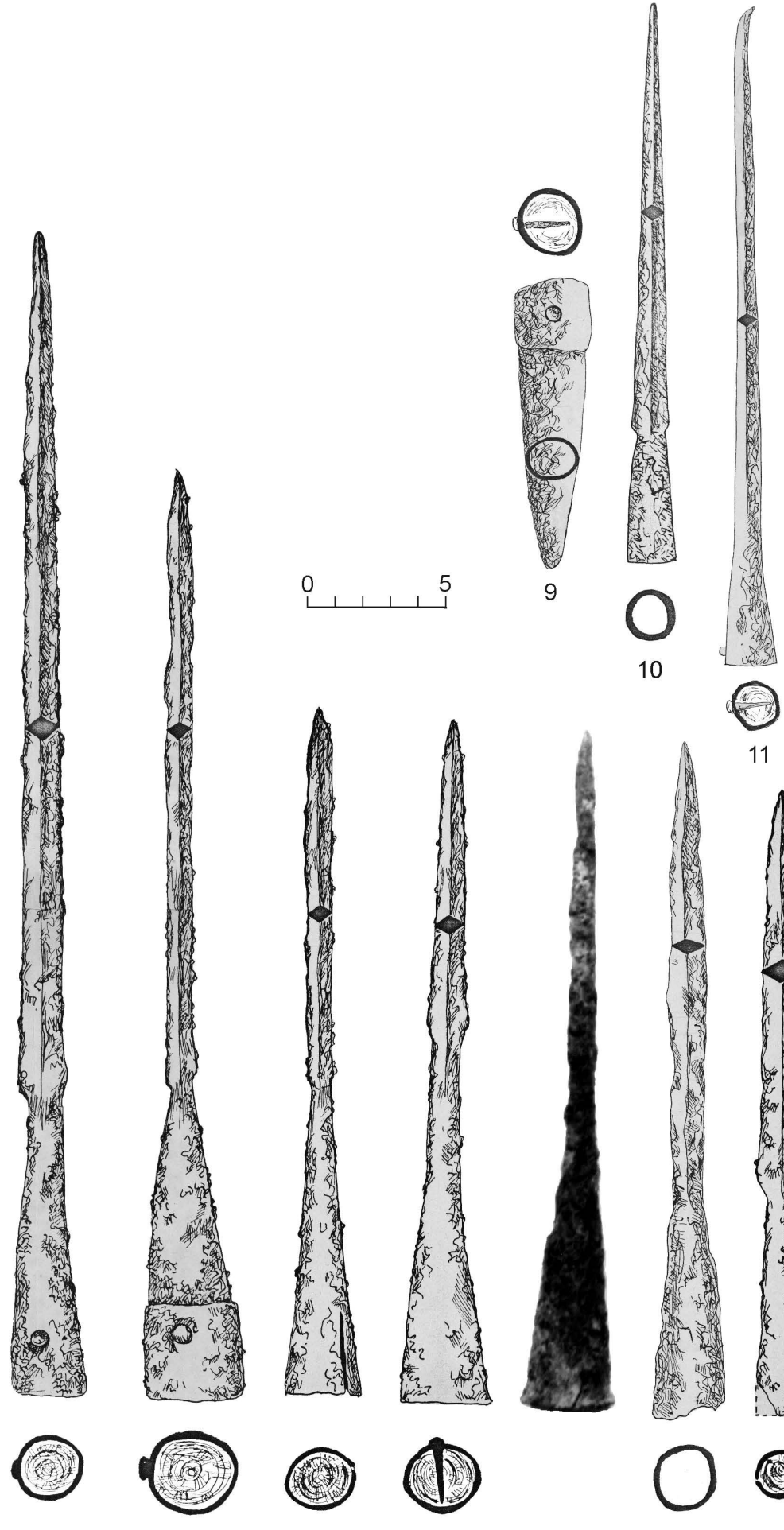

5
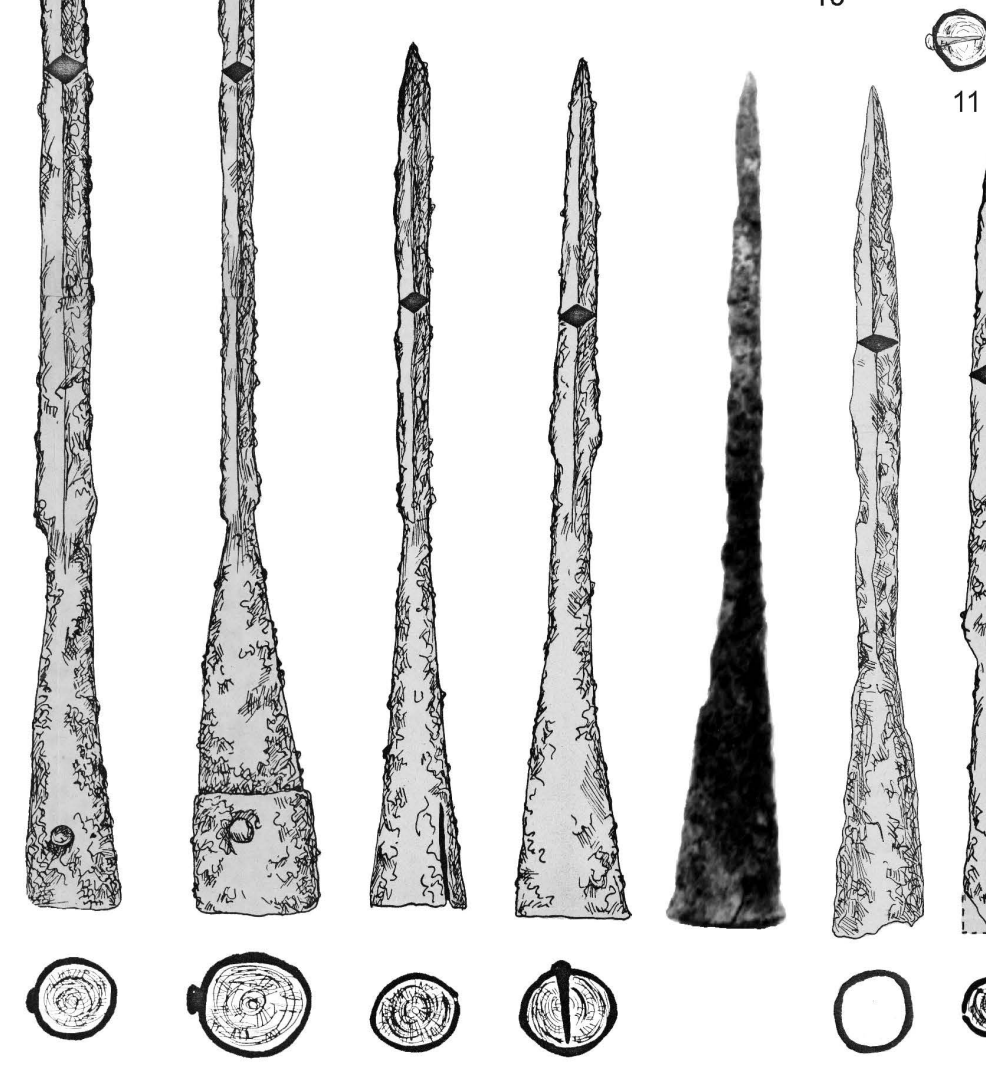

4

6
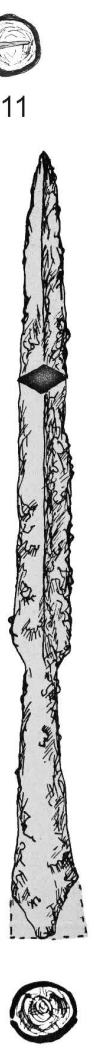

11

8

Рис. 2. Наконечники копий из погребений Келийского могильника XIII-XIV вв. из Высокогорной Ингушетии (1-5, 7-11 по: [Нарожный Е.И., 1989], 6- по: [Мужухоев, 1988]):

1 - наконечник из неизвестного погребения; 2 - погр. 22; 3 - погр. 69; 4 - погр. 132; 5 - погр. 186; 6 - погр. 32; 7 - погр. 185; 8 - погр. 198; 9, 11 - погр. 243; 10 - погр. 225

Fig. 2. Spearheads of the Keliysky burial ground of the $13^{\text {th }}-14^{\text {th }}$ centuries AD from Highland Ingushetia (1-5, 7-11 after: [Narozhny E.I., 1989], 6-after: [Muzhukhoev, 1988]):

1 - a spearhead from an unknown burial; 2 - burial 22; 3 - burial $69 ; 4$ - burial 132; 5 - burial 186; 6 - burial 32; 7 - burial 185;8 - burial 198; 9, 11 - burial 243; 10 - burial 225 


\section{СПИСОК ЛИТЕРАТУРЫ}

Басов В. И., Нарожный Е. И., Тихонов М. И., 2003. О двух типах наконечников копий с территории Северного Кавказа // Материалы и исследования по археологии Северного Кавказа. Вып. 2. Армавир : Центр археол. исслед. Армавир. гос. пед. ин-та. С. 105-111.

Виноградов В. Б., Нарожный Е. И., 1988. Монетные чеканы закавказских городов в северокавказских древностях XIII-XIV вв. // Научная конференция «Средневековые города и городская жизнь Кавказа (в свете археологических данных)». Тбилиси : Мецниереба. С. 44-46.

Виноградов В. Б., Нарожный Е. И., 1994. Погребения Келийского могильника (горная Ингушетия) // Археологические и этнографические исследования Северного Кавказа. Краснодар : КубГУ. С. 69-91.

Каминский В. Н., 1992. Вооружение племен аланской культуры Северного Кавказа I-XIII вв. : автореф. дис. ... канд. ист. наук. СПб. 21 с.

Кочкаров У. Ю., 2008. Вооружение воинов Северо-Западного Предкавказья VIII-XIV вв. (оружие ближнего боя). М. : Таус. $170 \mathrm{c}$.

Мамаев Р. Х., Дачаев И. С-Х., 2017. Археологические фонды Национального музея Чеченской Республики (работа по восстановлению коллекций) // Археология и история Юга России : сб. материалов Всерос. науч.-практ. конф., посвящ. 75-летию д-ра ист. наук, проф. М.Х. Багаева. Грозный : ЧГУ. С. 106-110.

Мамаев Р. Х., Кочкаров У. Ю., 2020. О саблях Келийского могильника (Горная Ингушетия) // Археологическое наследие Кавказа : актуальные проблемы изучения и сохранения. XXXI «Крупновские чтения» : материалы Междунар. науч. конф., посвящ. 50-летию «Крупновских чтений» и 50-летию Дербентской археологической экспедиции (Махачкала, 20-25 апреля 2020 г.). Махачкала : Мавраевь. С. 383-385.

Мужухоев М. Б., 1988. Отчет первого отряда археологической экспедиции Чечено-Ингушского научноисследовательского института истории, социологии и филологии за 1987. Грозный. 52 с. // Архив ИА РАН. Ф-1. Р-1. № 14083-14084.

Мужухоев М. Б., Нарожный Е. И., Чахкиев Д. Ю., 2017. Воинское погребение № 33 Келийского могильника (Горная Ингушетия) // Археология евразийских степей. № 5. С. 171-179.

Нарожный В. Е., 2004. Келийские склепы горной Ингушетии: некоторые аспекты изучения (по материалам раскопок 1987-1988 гг.) // Материалы и исследования по археологии Северного Кавказа. Вып. 4. Армавир : АГПИ. С. 358-359.

Нарожный В. Е., 2014. Население Горно-Ассинской котловины в XIII-XV веках : автореф. дис. ... канд. ист. наук. Владикавказ. $27 \mathrm{c}$.

Нарожный В. Е., Нарожный Е. И., 2008. Об аланском этнокомпоненте Келийского могильника XIII-XIV вв. (Горная Ингушетия) // Материалы по изучению историко-культурного наследия Северного Кавказа. Вып. VIII : «Крупновские чтения». 1971-2006 гг. М. : Памятники ист. мысли. С. 942.

Нарожный В. Е., Нарожный Е. И., 2009. Горная зона Восточного Придарьялья и золотоордынские владения (к изучению динамики взаимоотношений) // Донские древности. Диалог городской и степной культур на евразийском пространстве : материалы IV Междунар. конф., посвящ. памяти проф. МГУ Г.А. Федорова-Давыдова (г. Азов, 30 сентября - 3 октября 2008 г.). Вып. 10. Азов : АКМ. С. 373-387.

Нарожный В. Е., Нарожный Е. И., 2011. Из истории археологического изучения Чечено-Ингушетии (19861992 гг.) // Культурная жизнь Юга России. № 3 (41). Краснодар : КГУКИ. С. $29-35$.

Нарожный В. Е., Нарожный Е. И., 2012. Захоронение № 84 Келийского могильника (высокогорная Ингушетия) // Вестник Археологического центра им. Е.И. Крупнова. Вып. IV. Назрань : ООО «КЕП». С. 182-196.

Нарожный В. Е., Нарожный Е. И., 2021. О некоторых видах вооружения XIII-XIV вв. из высокогорной Ингушетии // Материалы Междунар. науч.-практ. конф. «Магас: древний и современный» (г. Магас, Республика Ингушетия, 12 апреля 2021 г). Ростов н/Д : Юж. изд. дом. С. 51-63.

Нарожный В. Е., Нарожный Е. И., Чахкиев Д. Ю., 2005. Погребение № 15 Келийского могильника (Горная Ингушетия) // Материалы и исследования по археологии Северного Кавказа. Вып. 5. Армавир : РИЦ АГПИ. С. 291-304.

Нарожный Е. И., 1989. Отчет об охранных археологических исследованиях Келийского могильника (Назрановского района ЧИАССР) в 1987 году. Грозный. 206 с. // Архив ИА РАН. Ф-1. Р-1. № 13181-13184.

Нарожный Е. И., 2003. О шлемах из сел. Ярыш-Марды и святилища Реком (Чечня и Северная Осетия) // Материалы и исследования по археологии Северного Кавказа. Вып. 2. Армавир : РИЦ АГПИ. С. 112-125. 
Нарожный Е. И., Мамаев Р. Х., 2018. Хоздоговорная археологическая лаборатория ЧИГУ им. Л.Н. Толстого (1986-1992 гг.) // Кавказский мир: проблемы образования, языка, литературы, истории и религии : материалы Междунар. науч.-практ. конф., посвящ. 80-летию ФГБОУ ВО «Чеченский государственный университет» (25-26 сентября 2018 г., г. Грозный). Грозный : ЧГУ. С. 270-283.

Нарожный Е. И., Мамаев Х. М., Чахкиев Д. Ю., Даутова Р. А., 1990. Полуподземные склепы Келийского могильника (по материалам охранных археологических исследований 1987 года в горной Ингушетии) // Археологические открытия на новостройках Чечено-Ингушетии. Грозный : Чеч.-Инг. кн. изд-во. С. 39-79.

Нарожный Е. И., Нарожный В. Е., Чахкиев Д. Ю., 2017. Погребения «копейщиков» Келийского могильника в высокогорной Ингушетии // Археология евразийских степей. № 5. Казань : Акад. наук Респ. Татарстан. C. $161-170$.

Нарожный Е. И., Нарожная Ф. Б., 2011. Средневековые монеты из высокогорной Ингушетии // Проблемы археологии Кавказа : материалы Междунар. науч. конф., посвящ. 70-летию Б.Н. Воронова (10-11 мая 2011 г., г. Сухум). Сухум : АбИГИ. С. 190-194.

Нарожный Е. И., Нарожная Ф. Б., 2012. Нумизматические материалы XIII-XIV вв. из высокогорной Ингушетии // Нумизматика Золотой Орды. Вып. 2. Казань : ИИ им. Ш. Марджани АН РТ. С. 66-73.

Сланов А. А., 2007. Военное дело алан I-XV вв. Владикавказ : СОИГСИ. 400 с.

Чахкиев Д. Ю., 1986. Оружие и вопросы военного искусства позднесредневековых вайнахов (XIII-XVIII вв.): археолого-этнографическое исследование) : автореф. дис. ... канд. ист. наук. М. 17 с.

Чахкиев Д. Ю., 1987. Копья и дротики у позднесредневековых вайнахов // Новые материалы по археологии и этнографии Чечено-Ингушетии. Грозный : Чеч.- Инг. кн. изд-во. С. 67-77.

Чахкиев Д. Ю., 2019. Оружие и вопросы военного искусства позднесредневековых ингушей и чеченцев (XIIIXVIII вв.). Магас : Юж. изд. дом. 378 с.

\section{REFERENCES}

Basov V.I., Narozhny E.I., Tihonov M.I., 2003. O dvuh tipah nakonechnikov kopiy s territorii Severnogo Kavkaza [About Two Types of Spearheads from the Territory of North Cacausus]. Materialy $i$ issledovaniya po arkheologii Severnogo Kavkaza [Materials and Research on the Archaeology of North Caucasus], iss. 2. Armavir, The Center for Archaeological Research of the Armavir State Pedagogical Institute, pp. 105-111.

Vinogradov V.B., Narozhny E.I., 1988. Monetnye chekany zakavkazskih gorodov v severokavkazskih drevnostyah XIII-XIV vv. [Coinage of Transcaucasian Cities in North Caucasian Antiquities of the XIII-XIV Centuries]. Nauchnaya konferentsiya «Srednevekovye goroda i gorodskaya zhizn' Kavkaza (v svete arheologicheskih dannyh)» [Scientific Conference "Medieval Cities and Urban Life of the Caucasus (in the Light of Archaeological Evidence)"]. Tbilisi, Metsniereba Publ., pp. 44-46.

Vinogradov V.B., Narozhny E.I., 1994. Pogrebeniya Keliyskogo mogilnika (gornaya Ingushetiya) [Burials of the Keliyskiy Cemetery (Mountain Ingushetia)]. Arheologicheskie i etnograficheskie issledovaniya Severnogo Kavkaza [Archaeological and Ethnographic Studies of the North Caucasus]. Krasnodar, KubSU, pp. 69-91.

Kaminskiy V.N., 1992. Vooruzhenie plemen alanskoy kul 'tury Severnogo Kavkaza I-XIII vv.: avtoref. dis. ... kand. ist. nauk [Armament of the Tribes of the Alanian Culture of the North Caucasus of the I-XIII Centuries. Cand. hist. sci. abs. diss.]. St. Petersburg. 21 p.

Kochkarov U.Yu., 2008. Vooruzhenie voinov Severo-Zapadnogo Predkavkaz'ya VIII-XIVvv. (oruzhie blizhnego boya) [The Arm of the North-West Ciscaucasia Warriors in VIII-XIV (Close-In Fighting Weapons)]. Moscow, Taus Publ. 170 p.

Mamaev R.Kh., Dachaev I.S., 2017. Arheologicheskie fondy Natsionalnogo muzeya Chechenskoy Respubliki (rabota po vosstanovleniyu kollektsii) [Archaeological Funds of the National Museum of the Chechen Republic (Work on the Restoration of Collections)]. Arkheologiya i istoriya Yuga Rossii: sbornik materialov Vserossiyskoy nauchno-prakticheskoy konferentsii, posvyashennoy 75-letiyu doktora istoricheskih nauk, professora M.H. Bagaeva [Archaeology and History of the South of Russia. Collection of materials of the AllRussian Scientific and Practical Conference Dedicated to the $75^{\text {th }}$ Anniversary of the Doctor of Historical Sciences, Professor M.H. Bagaev]. Groznyy, ChSU, pp. 106-110.

Mamaev R.Kh., Kochkarov U.Yu., 2020. O sablyah Keliyskogo mogilnika (Gornaya Ingushetia) [About Sabers of Keliyskiy Cemetery (Mountain Ingushetia)]. Archeologicheskoe nasledie Kavkaza: aktualnie problemy 
izucheniya i sohraneniya. XXXI «Krupnovskie chtenia»: materialy Mezhdunarodnoy nauchnoy konferentsii, posvyashenoy 50-letiu "Krupnovskih chteiniy» i 50-letiu Derbentskoy archeologicheskoy ekspspeditsii (Mahackala, 20-25 aprelya 2020 g.) [Archaeological Heritage of the Caucasus: Topical Problems of Study and Preservation. The XXXI ${ }^{\text {st }}$ Krupnov's Readings. Proceedings of the International Scientific Conference dedicated to the $50^{\text {th }}$ Anniversary of the Krupnov's Readings and the $50^{\text {th }}$ Anniversary of the Derbent Archaeological Expedition (Makhachkala, April 20-25, 2020)]. Makhachkala, Mavraev Publ., pp. 383-385.

Muzhukhoev M.B., 1988. Otchet pervogo otryada arheologicheskoy ekspeditsii Checheno-Ingushskogo nauchnoissledovatel'skogo instituta istorii, sotsiologii i filologii za 1987 [Report of the First Detachment of the Archaeological Expedition of the Chechen-Ingush Research Institute of History, Sociology and Philology for 1987]. 52 p. Arkhiv IA RAN, F-1, R-1, no. 14083-14084.

Muzhukhoev M.B., Narozhny E.I., Chahkiev D.Yu., 2017. Voinskoe pogrebenie № 33 Keliskogo mogilnika (Gornaya Ingushetiya) [Military Burial No.33 from Keliya Burial Ground (Mountain Ingushetia)]. Arheologiya evraziyskih stepey [Archaeology of the Eurasian Steppes], no. 5, pp. 171-179.

Narozhny V.E., 2004. Keliyskie sklepy gornoy Ingushetii: nekotorye aspekty izucheniya (po materialam raskopok 1987-1988 gg.) [Keli's crypts of Mountain Ingushetia: Some Aspects of Studying (Based on the Materials of Excavations in 1987-1988)]. Materialy i issledovaniya po arkheologii Severnogo Kavkaza [Materials and Research on archaeology of North Caucasus], iss. 4. Armavir, ASPI, pp. 358-359.

Narozhny V.E., 2014. Naselenie Gorno-Assinovskoy kotloviny v XIII-XV vekah: avtoref. dis. ... kand. ist. nauk [Population of Mountain-Assa Valley in XIII-XV Centuries. Cand. hist. sci.abs. diss.]. Vladikavkaz. 27 p.

Narozhny V.E., Narozhny E.I., 2008. Ob alanskom etnokomponente Keliiskogo mogilnika XIII-XIV vv. (Gornaya Ingushetiya) [About Alan's Ethnokomponent of Keliyskiy Cemetery XIII - XIV cc. (Mountain Ingushetiya)]. Materialy po izucheniyu istoriko-culturnogo naslediya Severnogo Kavkaza [Materials of Studying Historical-Archaeological Heritage of North Caucausus], iss. VIII: «Krupnov’s Reading». 1971-2006. Moscow, Pamyatniki istoricheskoy mysli Publ., p. 942.

Narozhny V.E., Narozhny E.I., 2009. Gornaya zona Vostochnogo Pridarialya i zolotordinskie vladeniya (k izucheniyu dinamiki vzaimootnosheniy) [Mountain zone of Eastern Pridariale and Golden Horde's Territory (to the Study of Dynamic of Relations)]. Donskie drevnosti. Dialog gorodskoy i stepnoy kultur na evraziyskom prostranstve: materialy IV Mezhdunarodnoy konferentsii, posvyashenoy pamyati prof. MGU FedorovaDavydova (g. Azov, 30 sentyabrya - 3 oktyabrya 2008 g.) [Don Antiquities. Dialog of Urban and Nomadic Culture on Eurasian Territory. Materials of IV International Conference, Dedicated to the Memory of prof. MSU G.A. Fedorov-Davydov (Azov, September, 30 - October, 3, 2008)], iss. 10. Azov, Azov Museum of Local Lore, pp. 373-387.

Narozhny V.E., Narozhny E.I., 2011. Iz istorii arheologicheskogo izucheniya Checheno-Ingushetii (1986-1992) [From the History of the Archaeological Study of Chechen-Ingushetia (1986-1992)]. Kul'turnaya zhizn'Yuga Rossii [Cultural life of the South of Russia], no. 3 (41). Krasnodar, KSUCA, pp. 29-35.

Narozhny V.E., Narozhny E.I., 2012. Zahoronenie № 84 Keliyskogo mogil’nika (vysokogornaya Ingushetiya) [Burial No. 84 of the Keliyskiy Cemetery (Highland Ingushetia)]. Vestnik Arheologicheskogo tsentra im. E.I. Krupnova [Bulletin of the Archaeological Center Named after E.I. Krupnov], iss. IV. Nazran, OOO «KEP» Publ., pp. 182-196.

Narozhny V.E., Narozhny E.I., 2021. O nekotoryh vidah vooruzheniya XIII-XIV vv. iz vysokogornoy Ingushetii [About Some Types of Weapons of the XIII-XIV Centuries from High-mountain Ingushetia]. Materialy Mezhdunarodnoy nauchno-prakticheskoy konferentsii «Magas: drevniy i sovremenniy» (g. Magas, Respublika Ingushetiya, 12 aprelya $2021 \mathrm{~g}$.) [Materials of the International Scientific and Practical Conference "Magas: Ancient and Modern”] (Magas, Republic of Ingushetia, April 12, 2021). Rostov-on-Don, Yuzhnyy izdatel'skiy dom Publ., pp. 51-63.

Narozhny V.E., Narozhny E.I., Chakhkiev D.Yu., 2005. Pogrebenie № 15 Keliyskogo mogilnika (Gornaya Ingushetiya) [Burial № 15 of the Keliyskiy Cemetery (Mountain Ingushetia)]. Materialy i issledovaniya po arkheologii Severnogo Kavkaza [Materials and Research on Archaeology of the North Caucasus], iss. 5. Armavir, RIC ASPI, pp. 291-304.

Narozhny E.I., 1989. Otchet ob ohrannyh arheologicheskih issledovaniyah Keliyskogo mogil'nika (Nazranovskogo rayona ChIASSR) v 1987 godu [Report on the Protective Archaeological Research of the Keliysky Burial Ground (Nazranovsky district of CHIASSR) in 1987]. Grozny. 206 p. Arkhiv IA RAN, F-1, R-1, no. 13181-13184. 
Narozhny E.I., 2003. O shlemah iz sel. Yarysh-Mardy i svyatilishcha Rekom (Chechnya i Severnaya Osetiya) [About Helmets from village Yarysh-Mardy and the Sanctuaries Recom (Chechnya and North Ossetia)]. Materialy $i$ issledovaniya po arkheologii Severnogo Kavkaza [Materials and Research on archaeology of the North Caucasus], iss. 2. Armavir, RIC ASPI, pp. 112-125.

Narozhny E.I., Mamaev R.Rh., 2018. Hozdogovornaya arheologicheskaya laboratoriya ChIGU im. L.N. Tolstogo (1986-1992 gg.) [Self-Supporting Contractual Archeological Laboratory of Chechen-Ingush State University of L.N. Tolstoy (1986-1992)]. Kavkazskiy mir: problemy obrazovaniya, yazyka, literatury, istorii i religii: materialy Mezhdunarodnoy nauchno-prakticheskaoy konferentsii, posvyashchennoy 80-letiyu FGBOU $V O$ «Chechenskiy gosudarstvennyy universitet» (25-26 sentyabrya 2018 g., g. Groznyy) [Caucasian World: Problems of Education, Language, Literature, History and Religion. International Scientific and Practical Conference Dedicated to the $80^{\text {th }}$ Anniversary of the Chechen State University (September 25-26, 2018, Grozny)]. Grozny, ChSU, pp. 270-283.

Narozhny E.I., Mamaev Kh.M., Chakhkiev D.Yu., Dautova R.A., 1990. Polupodzemnye sklepy Keliyskogo mogilnika (po materialam ohrannyh arheologicheskih issledovaniy 1987 goda v gornoy Ingushetii) [Semi-Underground Crypts of the Keliyskiy Cemetery (Based on the Materials of Protective Archaeological Research in 1987 in Mountainous Ingushetia)]. Arheologicheskie otkrytiya na novostroykah Checheno-Ingushetii [Archaeological Discoveries on New Constructions of Chechen-Ingushetia]. Grozny, Checheno-Ingushskoe knizhnoe izdatel'stvo Publ., pp. 39-79.

Narozhny E.I., Narozhny V.E., Chakhkiev D.Yu., 2017. Pogrebeniya «kopeyshchikov» Keliyskogo mogil'nika v vysokogornoy Ingushetii [Burials of 'Spearmen' from Keliya Burial Ground High-mountain Ingushetia]. Arheologiya evraziyskih stepey [Archaeology of the Eurasian Steppes], no. 5. Kazan, Academy of Science of Republic of Tatarstan, pp. 161-170.

Narozhny E.I., Narozhnaya F.B., 2011. Srednevekovie monety iz vysokogornoy Ingushetii [Medieval Coins from Highland Ingushetia]. Problemy arheologii Severnogo Kavkaza: materialy Mezhdunarodnoy nauchnoy nauchnoy konferentsii, posvashenoy 70-tiletiu V.B. Voronova (10-11 maya 2011 g., g. Sukhum) [Issues of Archaeology of North Caucasus. Materials of International Scientific Conference, Dedicated to $70^{\text {th }}$ of B.N. Voronov (May 10-11, 2011, Suhkum)]. Sukhum, AIGS, pp. 190-194.

Narozhny E.I., Narozhnaya F.B., 2012. Numizmaticheskie materiali XIII-XIV iz Gornoy Ingushetii [Numizmatic Materials XIII-XIV cc. from Highland Ingushetiya]. Numizmatica Zolotoy Ordy [Numizmatic of Golden Horde], iss. 2. Kazan, Institute of History named after S. Mardjani Academy of Science of Republic of Tatarstan, pp. 66-73.

Slanov A.A., 2007. Voennoe delo alan $I-X V v v$. [Military Affairs of the Alan I-XV Centuries]. Vladikavkaz, SOIHSR. 400 p.

Chakhkiev D.Yu., 1986. Oruzhie i voprosy voennogo iskusstva pozdnesrednevekovyh vaynahov (XIII-XVIII vv.): arheologo-etnograficheskoe issledovanie): avtoref. dis.... kand. ist. nauk [Weapons and Issues of Military Art of the Late Medieval Vainahs (XIII-XVIII centuries) (Archaeological and Ethnographic Research). Cand. hist. sci. abs. diss.]. Moscow. 17 p.

Chakhkiev D.Yu., 1987. Kop'ya i drotiki u pozdnesrednevekovyh vaynahov [Spears and Javelins from the Late Medieval Vainakhs]. Novye materialy po arheologii i etnografii Checheno-Ingushetii [New Materials on Archaeology and Ethnography of Chechen-Ingushetia]. Grozny, Checheno-Ingushskoe knizhnoe izdatel'stvo Publ., pp. 67-77.

Chakhkiev D.Yu., 2019. Oruzhie i voprosy voennogo iskusstva pozdnesrednevekovyh ingushey $i$ chechencev (XIII-XVIII vv.) [Weapons and Issues of Military Art of the Late Medieval Ingush and Chechens (XIIIXVIII Centuries)]. Magas, Yuzhnyy izdatel'skiy dom Publ. 378 p. 


\section{Information About the Authors}

Robert H. Gagloiti, Candidate of Sciences (History), Director, South-Ossetian Scientific Research Institute named after Z.N. Vaneev, Prosp. Alana Dzhioeva, 3, 100001 Tskhinval, South Ossetia, berd-07-gagloev@yandex.ru, https://orcid.org/0000-0001-8834-8228

Umar U. Kochkarov, Candidate of Sciences (History), Head of the Scientific Archive, Institute of Archeology of the Russian Academy of Sciences, Dm. Ulyanova St, 19, 117292 Moscow, Russian Federation, umar_k@mail.ru, https://orcid.org/0000-0001-9552-279X

Rashid Kh. Mamaev, Assistant, Department of History of Ancient World and Middle Ages, Chechen State University, A. Sheripova St, 32, 364024 Grozny, Russian Federation, borz85@list.ru, https://orcid.org/0000-0001-6498-262X

Vitaliy E. Narozhnyi, Candidate of Sciences (History), Independent Researcher, Armavir, Russian Federation, vitanar21@yandex.ru, https://orcid.org/0000-0001-5320-2245

Evgeniy I. Narozhnyi, Doctor of Sciences (History), Professor, Department of World History, Karachay-Cherkess State University named after U.D. Aliyev, Lenina St, 29, 369202 Karachayevsk, Russian Federation, zai_ein@mail.ru, https://orcid.org/0000-0002-4628-4382

\section{Информация об авторах}

Роберт Хазбиевич Гаглойты, кандидат исторических наук, директор, Юго-Осетинский научно-исследовательский институт им. 3.Н. Ванеева, просп. Алана Джиоева, 3, 100001 г. Цхинвал, Республика Южная Осетия, berd-07-gagloev@yandex.ru, https://orcid.org/0000-0001-8834-8228

Умар Юсуфович Кочкаров, кандидат исторических наук, заведующий научным архивом, Институт археологии РАН, ул. Дм. Ульянова, 19, 117292 г. Москва, Российская Федерация, umar_k@mail.ru, https://orcid.org/0000-0001-9552-279X

Рашид Хамидович Мамаев, ассистент кафедры истории Древнего мира и средних веков, Чеченский государственный университет, ул. А. Шерипова, 32, 364024 г. Грозный, Российская Федерация, borz85@list.ru, https://orcid.org/0000-0001-6498-262X

Виталий Евгеньевич Нарожный, кандидат исторических наук, независимый исследователь, г. Армавир, Российская Федерация, vitanar21@yandex.ru, https://orcid.org/0000-0001-5320-2245

Евгений Иванович Нарожный, доктор исторических наук, профессор кафедры всеобщей истории, Карачаево-Черкесский государственный университет им. У.Д. Алиева, ул. Ленина, 29, 369202 г. Карачаевск, Российская Федерация, zai_ein@mail.ru, https://orcid.org/0000-0002-4628-4382 